\title{
Determinants of Midwife Performance on Antenatal Care in Surakarta and Karanganyar, Central Java
}

\author{
Titis Eka Gusti1), Didik Tamtomo²), Bhisma Murti1) \\ 1)Masters Program in Public Health, Universitas Sebelas Maret \\ 2)Faculty of Medicine, Universitas Sebelas Maret
}

\begin{abstract}
Background: A high maternal mortality rate is one of the major health problems in developing countries. Midwives have an important role to reduce maternal mortality rate by looking after a pregnant women and her baby throughout a phase of antenatal care, during labor and birth, and for up to 28 days after the baby has been born. The WHO Expert Committee on Midwifery stated that the competence of the midwife must extend beyond the provision of service at the time of delivery to total antenatal and postnatal care. This study aimed to examine the determinants of midwife performance on antenatal care in Surakarta and Karanganyar, Central Java.

Subjects and Method: This was an analytic observational study with a cross-sectional design. The study was conducted at 25 community health centers in Surakarta and Karanganyar, Central Java, from April to May 2018. A total sample of 200 midwives was selected by simple random sampling. The dependent variable was midwife performance. The independent variables at level 1 of multilevel modeling (MLM) were age, tenure, motivation, knowledge, training, facility, and leadership. Community health center (Puskesmas) was taken as level 2 in the MLM. The data were collected by questionnaire and analyzed by MLM.

Results: Longer tenure $(b=1.57 ; 95 \% C I=0.11$ to 3.02; $p=0.035)$, provision of training $(b=1.92$; $95 \% \mathrm{CI}=0.45$ to $3.40 ; \mathrm{p}=0.011)$, high motivation $(\mathrm{b}=1.48 ; 95 \% \mathrm{CI}=-0.13$ to $3.09 ; \mathrm{p}=0.072)$, better knowledge $(b=1.61 ; 95 \% \mathrm{CI}=0.03$ to $3.19 ; \mathrm{p}=0.046)$, facility $(\mathrm{b}=1.44 ; 95 \% \mathrm{CI}=0.14$ to 2.73 ; $\mathrm{p}=0.030)$, strong leadership $(\mathrm{b}=1.66 ; 95 \% \mathrm{CI}=0.18$ to $3.13 ; \mathrm{p}=0.028)$, and age $\geq 27$ years $(\mathrm{b}=2.08$; $95 \% \mathrm{CI}=0.04$ to $4.12 ; \mathrm{p}=0.046)$ were positively associated with better performance of midwives. A large portion of variation in midwives performance was determined at Puskesmas level with ICC= $45.78 \%$.

Conclusion: Longer tenure, provision of training, high motivation, better knowledge, facility, strong leadership, and age $\geq 27$ years are positively associated with better performance of midwives. Community health center has an important contextual effect on midwife performance.
\end{abstract}

Keywords: midwife, performance, age, tenure, motivation, training, leadership, community health center

Correspondence:

Titis Eka Gusti. Masters Program in Public Health, Universitas Sebelas Maret, Jl. Ir. Sutami 36 A, Surakarta 57126, Central Java. Email: titisekagusti@gmail.com

\section{BACKGROUND}

Maternal Mortality Rate (MMR) and Infant Mortality Rate (IMR) are two of indicators of health development in the National Medium Term Development Plan (RPJMN) 2015-2019 and SDG's in 2015-2030 (Bappenas, 2015). According to the results of the 2015 AKI Population Survey (SUPAS), in Indonesia, there were 305 maternal deaths per 100,000 live births, which is still quite high compared to the target of SDG's which by 2030 can reach below 70 per 100,000 live births. Maternal and infant deaths are caused by several factors, namely: direct obstetric causes, including bleeding and eclampsia, and indirect causes, such as malaria, HIV, and anemia, which may be worsened during pregnancy. The term 
pregnancy-related death includes all deaths during pregnancy, labor, and the postpartum period, regardless of the cause (Hanson et al, 2015).

The direct factors of maternal mortality in Central Java is usually because of bleeding (21.26\%), hypertension in pregnancy (27.08\%), infections (4.82\%), circulatory system disorders (13.29\%), metabolic disorders (33\%) and other causes (33.22\%). Indirect factors causing maternal mortality include lack of access to quality health services, especially timely emergency services, motivated by late recognition of danger signs and decisions, late access to health facilities, and late in getting services in health facilities (Central Java Health Office, 2016 ).

One of government efforts to suppress MMR and IMR is to bring the health services closer. Community Health Center is a health service facility that organizes public health efforts and individual health efforts of the first level by prioritizing promotive and preventive efforts (Ministry of Health, 2014). One of minimum service standards that must be achieved is health services in pregnant women (Ministry of Health, 2016).

It is known that pregnancy care is very important for the mother because during pregnancy, it aims to monitor and improve the health of mother and fetus. Regular monitoring can detect early complications during pregnancy that affect both labor and childbirth (Yeoh et al, 2016).

The example of causes of maternal deaths in Surakarta in 2016 is that two people died during pregnancy, one died at the time of delivery and one died during the puerperium (Surakarta city health office, 2016).

Midwives have a very important role as primary care providers of maternal health at the most vulnerable time in the life cycle. Almost every mother-birth experience started from pregnancy was helped by a midwife (WHO, 2014 in Bekru 2017). Midwife performance in Antenatal Care services can be assessed from the achievement of the first visit of pregnancy (K1) and the fourth visit of pregnancy (K4) and the provision of $\mathrm{Fe}$ tablet (Dinkes Kota Surakarta, 2016).

The achievement of K1 of Surakarta in 2016 was $93.4 \%$ and $\mathrm{K} 4$ was $92.7 \%$. Achievement of $\mathrm{Fe}$ tablets in pregnant women in Surakarta is only $80.92 \%$ (Surakarta City Health Office, 2016). In Karanganyar Regency, the achievement of $\mathrm{K} 1$ in 2016 is $93 \%$. The achievement of $\mathrm{K}_{4}$ is $93 \%$ and giving $\mathrm{Fe}$ tablet equal to $90 \%$ and still less than the target of Ministry of Health that is $100 \%$ (Central Java Health Office, 2016). The performance of midwives is very influential on the achievement of health services which is expected to have an impact on the improvement of pregnancy service in Surakarta and in Karanganyar Regency.

\section{SUBJECTS AND METHOD}

\section{Study design}

This was an analytic observational study with a cross sectional design. The study was conducted in puskesmas (community health center) in Surakarta and Karanganyar Districts, Central Java, from April to May 2018.

\section{Population and sample}

The source population was midwive at Surakarta and Karanganyar community health center. A sample of 8 midwives from each puskesmas was selected by simple random sampling. Puskesmas was selected by stratified random sampling.

\section{Study variables}

The dependent variable was midwife performance. The independent variables were age, employment, motivation, know- 
ledge, training, health facility, and leadership.

\section{Operational definition of variables}

Performance was defined as midwife assessment of the performance of the work in which it is the responsibility of the midwife. The data were collected by questionnaire. The measurement scale was continuous.

Midwife age was defined as the time (year) from the birth to the study was conducted. The data were collected by questionnaire. The measurement scale was continuous.

Tenure was defined as the length of midwife working in puskesmas from the first day of work until the study was conducted. The data were collected by questionnaire. The measurement scale was continuous.

Motivation was defined as midwife motivation to perform ANC. The data were collected by questionnaire. The measurement scale was continuous.

Knowledge was defined as a collection of information and understanding of the respondents about ANC services. The data were collected by questionnaire. The measurement scale was continuous.

Training was defined as a special education that has been followed by officers associated with ANC services. The data were collected by questionnaire. The measurement scale was categorical.

Facility was defined as facility and infrastructure available in accordance with the needs of the implementation of ANC services in Community Health Centers.

Leadership was defined as the midwife assessment of the superior's ability to interpret, supervise and support the implementation of ANC services.

\section{Data Analysis}

Univariate analysis was conducted to see the frequency distribution and percentage characteristics of the research subjects. Bivariate analysis was conducted to study the relation between performance of midwife and independent variable using chi-square test and odds ratio calculation (OR) with confidence level (CI) equal to 95\%. Furthermore, multivariate analysis was done by a multilevel logistic model.

\section{Research Ethics}

The research ethics included informed consent, anonymity, confidentiality and ethical clearance. The ethical clearance in this research was conducted at Dr. Moewardi hospital, Surakarta.

\section{RESULTS}

\section{Univariate Analysis}

Table 1 shows that the subjects with less performance consisted of 80 midwives (40\%), and those who performed well were 120 respondents (60\%). Midwives who have a working period of $<3$ years were 87 (43.5\%), and who have a working period of $\geq 3$ years were 113 midwives (56.5\%). Midwives who have never had ANC training are 87 (43.5\%), and who have had ANC training were 113 midwives (56.5\%). Midwives who have less motivation are 87 (43.5\%), and those who have good motivation were 113 midwives (56.5\%). Midwives who have less knowledge were 83 (41.5\%), and those who have good knowledge were 117 midwives (58.5\%).

Midwives who have less ANC facilities are 66 midwives (33\%), and those who have good ANC facilities were 134 midwives (67\%). Midwives with less leadership assessments were 87 midwives (43.5\%), and those who have a good leadership assessment were 113 midwives (56.5\%). Subjects with age $<27$ years were 92 (46\%), and midwives with age $\geq 27$ years were 108 (54\%). 
Journal of Health Policy and Management (2018), 3(1): 11-19

https://doi.org/10.26911/thejhpm.2018.03.01.02

Table 1. Univariate Analysis

\begin{tabular}{lcc}
\hline \multicolumn{1}{c}{ Variable } & n & \% \\
\hline Midwife performance & & \\
Poor & 80 & 40 \\
Good & 120 & 60 \\
Tenure & & \\
$<3$ years & 87 & 43.5 \\
$\geq 3$ years & 113 & 56.5 \\
Training & & \\
Never & 87 & 43.5 \\
Ever & 113 & 56.5 \\
Motivation & & \\
Weak & 87 & 43.5 \\
Strong & 113 & 56.5 \\
Knowledge & & \\
Low & 83 & 41.5 \\
High & 117 & 58.5 \\
Facility & & \\
Poor & 66 & 33 \\
Good & 134 & 67 \\
Leadership & & \\
Poor & 87 & 43.5 \\
Good & 113 & 56.5 \\
Age & & \\
$<27$ years & 92 & 46 \\
$\geq 27$ years & 108 & 54 \\
\hline
\end{tabular}

\section{Bivariate analysis of midwife performance determinant}

Bivariate analysis looked at the relationship of independent variables (length of service, training, motivation, knowledge, facilities, leadership, and age) with the dependent variable (midwife performance on ANC services). The result of bivariate analysis can be seen in table 2 .

\section{Multilevel Analysis}

Table 3 showed the result of ICC $=45.78 \%$. This indicator indicated that Community Health Centers in each strata have a contextual effect on the midwives performance variation on ANC service by $45.78 \%$. The number was greater than the standard of thumb size role of $8-10 \%$ then the contextual effect of the Community Health Center shown from multilevel analysis was very important to note.

Multivariate effect explained about the effects of more than independent variable which were work period, training, motivation, knowledge, facility, leadership, and age to one dependent variable that was performance of midwives on ANC service.

There was an effect between midwives working period on midwives performance on ANC services which was statistically significant. Midwives who have a working period of $\geq 3$ years increased the likelihood of having a good performance than midwives who have a working period of $<3$ years $(\mathrm{b}=1.57 ; 95 \% \mathrm{CI}=0.11$ to $3.02 ; \mathrm{p}=$ o.035). There was an effect between training on ANC services which was statistically significant. Midwives who have conducted training increased the likelihood of having a good performance than midwives who have never done the training $(b=1.92 ; 95 \% \mathrm{CI}=$ 0.45 to $3.40 ; \mathrm{p}=0.011$ ).

There was an effect between midwives motivation on ANC services which was statistically significant. Well-motivated midwives increased the likelihood of having a better performance than midwives who have lack of motivation $(b=1.48 ; 95 \% \mathrm{CI}=$ 0.13 to $3.09 ; p=0.072$ ). There was an effect between midwives knowledge on ANC services which was statistically significant. Midwives who have good knowledge increased the likelihood of having a better performance than midwives with lack of knowledge $(b=1.61 ; 95 \% \mathrm{CI}=0.03$ to 3.19 ; $\mathrm{p}=0.046)$.

There was an effect between ANC facilities availability on ANC services which was statistically significant. Midwives who have good facilities increased the likelihood of having a better performance than midwives with lack of facilities $(b=1.44$; 95\% $\mathrm{CI}=0.14$ to $2.73 ; \mathrm{p}=0.030$ ).

There was an effect between leadership on ANC services which was statistically significant. Midwives who have leaders with good leadership increased the likelihood of having a good performance than midwives who have leaders with lack of leadership $(b=1.66 ; 95 \% C I=0.18$ to $3.13 ; p=0.028)$. 
There was an effect between midwives age on ANC services which was statistically significant. Midwives who were $\geq 27$ years old increased the likelihood of having a better performance than midwives who have a working period of $<27$ years $(b=$ $2.08 ; 95 \% \mathrm{CI}=0.04$ to $4.12 ; \mathrm{p}=0.046)$.

Table 2. The result of bivariate analysis on the determinants of midwife performance

\begin{tabular}{|c|c|c|c|c|c|c|c|c|c|}
\hline \multirow{2}{*}{$\begin{array}{c}\text { Inde- } \\
\text { pendent } \\
\text { Variable }\end{array}$} & \multicolumn{2}{|c|}{$\begin{array}{c}\text { Less } \\
\text { Performance }\end{array}$} & \multicolumn{2}{|c|}{$\begin{array}{c}\text { Good } \\
\text { Performance }\end{array}$} & \multicolumn{2}{|c|}{ Total } & \multirow[t]{2}{*}{ OR } & \multirow[t]{2}{*}{$95 \%$ CI } & \multirow{2}{*}{$\mathbf{p}$} \\
\hline & $\mathbf{n}$ & $\%$ & $\mathbf{n}$ & $\%$ & $\mathbf{n}=\mathbf{2 0 0}$ & $\%$ & & & \\
\hline Tenure & & & & & & & & $7 \cdot 37$ to & $<0.001$ \\
\hline$<3$ years & 63 & 72.4 & 24 & 27.6 & 87 & 100 & 14.24 & 29.79 & \\
\hline$\geq 3$ years & 17 & 15 & 96 & 85 & 113 & 100 & & & \\
\hline Training & & & & & & & & 2.96 to & $<0.001$ \\
\hline Never & 54 & 62.1 & 33 & 37.9 & 87 & 100 & 5.48 & 10.14 & \\
\hline Ever & 26 & 23 & 87 & 77 & 113 & 100 & & & \\
\hline Motivation & & & & & & & & 15.81 to & $<0.001$ \\
\hline Weak & 69 & 79.3 & 18 & 20.7 & 87 & 100 & 35.55 & 79.89 & \\
\hline Strong & 11 & 9.7 & 102 & 90.3 & 113 & 100 & & & \\
\hline Knowledge & & & & & & & & 11.57 to & $<0.001$ \\
\hline Poor & 65 & 78.3 & 18 & 21.7 & 83 & 100 & 24.56 & 52.12 & \\
\hline Good & 15 & 12.8 & 102 & 87.2 & 117 & 100 & & & \\
\hline Facility & & & & & & & & 6.83 to & $<0.001$ \\
\hline Poor & 52 & 78.8 & 14 & 21.2 & 66 & 100 & 14.06 & 28.95 & \\
\hline Good & 28 & 20.9 & 106 & 79.1 & 134 & 100 & & & \\
\hline Leadership & & & & & & & & 13.73 to & $<0.001$ \\
\hline Poor & 68 & 78.2 & 19 & 21.8 & 87 & 100 & 30.12 & 66.07 & \\
\hline Good & 12 & 10.6 & 101 & 89.4 & 113 & 100 & & & \\
\hline Age & & & & & & & & 12.10 to & $<0.001$ \\
\hline$<27$ years old & 69 & 75 & 23 & 25 & 92 & 100 & 26.46 & 57.83 & \\
\hline$\geq 27$ years old & 11 & 10.2 & 97 & 89.8 & 108 & 100 & & & \\
\hline
\end{tabular}

Table 3. The results of multilevel logistic regression analysis on the midwife performance

\begin{tabular}{|c|c|c|c|c|}
\hline \multirow{2}{*}{ Variable } & \multirow{2}{*}{$\begin{array}{l}\text { Coefficient } \\
\text { (b) }\end{array}$} & \multicolumn{2}{|c|}{ 95\% CI } & \multirow[b]{2}{*}{$\mathbf{p}$} \\
\hline & & Lower limit & Upper limit & \\
\hline \multicolumn{5}{|l|}{ Fixed Effect } \\
\hline Tenure & 1.57 & 0.11 & 3.02 & 0.035 \\
\hline Training & 1.92 & 0.45 & 3.40 & 0.011 \\
\hline Motivation & 1.48 & -0.13 & 3.09 & 0.072 \\
\hline Knowledge & 1.61 & 0.03 & 3.19 & 0.046 \\
\hline Facility & 1.44 & 0.14 & 2.73 & 0.030 \\
\hline Leadership & 1.66 & 0.18 & 3.13 & 0.028 \\
\hline Age & 2.08 & 0.04 & 4.12 & 0.046 \\
\hline \multicolumn{5}{|l|}{ Random Effect } \\
\hline Community Health Center & 2.78 & 0.58 & 13.38 & 0.006 \\
\hline \multicolumn{5}{|l|}{$\operatorname{Var}$ (Constanta) } \\
\hline $\mathrm{ICC}=45.78 \%$ & & & & \\
\hline Likelihood Ratio Test $\mathrm{p}=-46.75$ & & & & \\
\hline
\end{tabular}

\section{DISCUSSION}

1. The effect of tenure on midwives performance

The result of analysis showed that there was an effect between working period and midwives performances. Tenure $\geq 3$ years increased the likelihood good performance $(b=1.57 ; 95 \% \mathrm{CI}=0.11$ to $3.02 ; \mathrm{p}=0.035)$.

The result of this study is consistent with a study by Kustiyati et al. (2017), 
which stated that working period affected midwives performance in delivery planning and prevention of complications program in Sukoharjo District. Research by Dan et al., (2015) reported a positive relationship between working period and midwives performances in South Minahasa District Health Center.

Gibson (1996) in Handayani (2012) stated that working period or experience affected the performance. Other theory which was in line with this study also stated by Robin (2003), working period showed a positive relationship with someone's work productivity. Working period was a good rationale for employee's productivity. A person who has been working for a long time has a broader perspective and experience that would formed her behavior.

\section{The effect of training on midwives performance}

The result of analysis showed that there was an effect between training and midwives performances on ANC services which was statistically significant. Midwives who have conducted training increased the likelihood of having a good performance than midwives who have never done the training $(\mathrm{b}=$ $1.92 ; 95 \% \mathrm{CI}=0.45$ to $3.40 ; \mathrm{p}=0.011$ ).

The result of this study was in line with a study by Mizawati et al, (2016) which stated that midwives who received training had higher performance than midwives who had not received training with a difference of 2 points ( $95 \% \mathrm{CI}=1.71^{-}$ 2.51 ) the study was conducted on midwives performance in early detection of malaria during pregnancy in Central Bengkulu District. A study by Aldusary et al, (2018) also stated that there was a significant effect between training and performance. The study used an experimental method where there was a pre-training group of Cardiopulmonary Resusitation (CPR) and post-training (CPR). Pre-training groups showed lower results than the post-training group.

3. The effect of motivation on midwives performance

The result of analysis showed that there was an effect between midwives motivation and midwives performances on ANC services which was statistically significant. Wellmotivated midwives increased the likelihood of having a better performance than midwives with lack of motivation $(\mathrm{b}=1.48$; $95 \% \mathrm{CI}=-0.13$ to $3.09 ; \mathrm{p}=0.072$ ).

This study is consistent with a study by Marfu'ah (2016) which stated that midwives who have good work motivation in doing the duties and job responsibilities have the potential to have better performance than midwives who have low motivation with the score: $(\mathrm{b}=0.15 ; 95 \% \mathrm{CI}=0.01$ to $0.29 ; \mathrm{p}=0.035$ ).

The results of other study showed that motivation has a significant effect on the midwives performance in village in performing the data on maternal and child health book monitoring in Sragen District (Cahyani et al, 2016). Motivation was related to performance because with a high motivation of midwives in Community Health Center, it can motivated the midwives to work better. The motivation of midwives in the Community Health Center was supported by the role of the Community Health Center leader in involving the midwives in the activities carried out by the Community Health Center, giving the midwives an opportunity to move forward, and be accepted and appreciated by the community (Dan et al, 2015).

\section{The effect of knowledge on mid- wives performance}

The result of analysis showed that there was an effect between midwives knowledge and midwives performances on ANC services which was statistically significant. Midwives with good knowledge increased the 
likelihood of having a better performance than midwives with lack of knowledge $(b=1.61 ; 95 \% \mathrm{CI}=0.03$ to $3.19 ; \mathrm{p}=0.046)$. The result of this study was in line with a study by Kustiyati et al., (2017), which stated that there was a significant relationship between knowledge and midwives performance in monitoring the recording of Health Service Center reporting in the work area of Magelang Health Office.

The result of a study by Korner (2014) showed that there was an effect between knowledge and the performance of medical personnel team. A study by Harmiyati et al., (2016) also showed the result that knowledge affected health personnel performance at Community Health Center in Palembang.

\section{The effect of facility on midwives performance}

The result of analysis showed that there was an effect between midwives facilities and midwives performances on ANC services which was statistically significant. Midwives who have good facilities increased the likelihood of having a better performance than midwives with lack of facilities $(b=$ $1.44 ; 95 \% \mathrm{CI}=0.14$ to $2.73 ; \mathrm{p}=0.030)$.

Bhatnagar and George (2016) stated that the availability of health equipment affected the high performance of health personnel, health personnel felt more proud and easier in doing their work if they were supported by good facilities.

The result of this study was in line with a study by Wulandari et al, (2017) which stated that facilities and infrastructure affected the performance of village midwives in providing ANC services in Jember District.

\section{The effect of leadership on mid- wives performance}

The result of analysis showed that there was an effect between leadership and midwives performances on ANC services which was statistically significant. Midwives who have leaders with good leadership increased the likelihood of having a good performance than midwives who have leaders with lack of leadership $(b=1.66 ; 95 \% \mathrm{CI}=0.18$ to 3.13 ; $\mathrm{p}=0.028$ ).

The result of this study was in line with a study by Awases et al., (2013) which stated that performance monitoring by leaders improved the service performance in patients. Al-Ahmadi (2009) also mentioned that leadership behavior has a positive effect on health personnel performance. The reward from a leader can improve work performance or officer performance so that nonfinancial awards were equally important as financial rewards.

A study by Barnes (1992) in Shin (2015) showed good leadership results have a positive effect on Emotional Intelligence and performance. Poor leadership was identified as a cause of poor performance in the health sector (Kuria, 2016).

\section{The effect of age on midwives performance}

The result of analysis showed that there was an effect between midwives age and midwives performances on ANC services which was statistically significant. Midwives who were $\geq 27$ years old increased the likelihood of having a better performance than midwives who have a working period of $<27$ years $(b=2.08 ; 95 \% \mathrm{CI}=0.04$ to $4.12 ; \mathrm{p}=$ 0.046). Other results indicated that mature age affected the performance (Sheard, 2009).

\section{The effect of health center levels on midwives performance}

The results of this study showed that the variation of performance by $45.78 \%$ was determined by the variables at the level of Community Health Center, therefore, it was highly important. The workplace was very influential on the performance of midwives. 
This was in line with a study by Ae and Sook (2016) which stated that performance was strongly affected by the workplace, the study was conducted on the nurses performance in the hemodialysis unit.

\section{RFERENCE}

Ae J, Sook B (2016). Effect of Work Environment on Nursing Performance of Nurses in Hemodialysis Units: Focusing on the Effects of Job Satisfaction and Empowerment, 22(2): 178-188.

Al-Ahmadi H (2009). Factors affecting performance of hospital nurses in Riyadh Region, Saudi Arabia. International Journal of Health Care Quality Assurance, 22(1): 40-54. doi: 10.1108/09526860910927943.

Awases MH, Bezuidenhout MC, Roos JH (2013). Factors affecting the performance of professional nurses in Namibia. Curationis, 36(1): 1-8. doi: 10.4102/curationis.v36i1.108.

Bappenas (2015). Kebijakan Perencanaan Pembangunan Kesehatan (RPJMN 2015-209)/Perpres No 2/2015. Bappenas, Jakarta, (1): 224-228.

Barnes C (1992). Personnel review. Disability and employment, 21(6): 55 . doi: 10.1108/00483481011075611.

Bhatnagar A, George AS (2016). Motivating health workers up to a limit: partial effects of performance-based financing on working environments in Nigeria. Health policy and planning, 31(7): 868-877. doi: 10.1093/hea$\mathrm{pol} / \mathrm{czw002}$.

Cahyani RN, et al. (2016). Kelengkapan Pengisian Dan Pemanfaatan Data Pada Buku Kia Oleh Bidan Desa Di Kabupaten Sragen Tahun 2016.

Dan M, et al. (2015). Pendahuluan Pembangunan Kesehatan sebagaimana yang disebutkan dalam Undangundang Kesehatan No. 36 tahun
2009, bertujuan untuk meningkatkan kesadaran, kemauan dan kemampuan hidup sehat bagi setiap orang agar dapat terwujud derajat kesehatan masyarakat.

Dinas Kesehatan Kota Surakarta (2016). Profil Kesehatan Kota Surakarta tahun 2015. Surakarta: Bagian Kesehatan Masyarakat DKK Surakarta.

Dinas Kesehatan Provinsi Jawa Tengah (2016). Profil Kesehatan Provinsi Jawa Tengah tahun 2015. Semarang: Depkes Jateng.

Handayani T (2012). Faktor - faktor yang berhubungan dengan kinerja petugas MTBS (manajemen terpadu balita sakit) di puskesmas kabupaten kulon progo tahun 2012. Depok: Tesis Fakultas Ilmu Kesehatan Masyarakat Universitas Indonesia.

Hanson C (2015). Maternal mortality and distance to facility-based obstetric care in rural southern Tanzania: a secondary analysis of cross-sectional census data in 226,000 households. The Lancet Global Health.

Harmiyati L, Kurdi FN, Sulastri S (2016). Pengaruh Karakteristik dan Kapabilitas Individu Serta Karakteristik Organisasi terhadap Persepsi Kinerja Perawat Perkesmas di Puskesmas Kota Palembang. Jurnal Kedokteran dan Kesehatan, 3(1): 391-399. Available at: http://ejournal.unsri.ac.id/index.$\mathrm{php} / \mathrm{jkk} /$ article/view/2866.

Kementerian Kesehatan Republik Indonesia (2016). Peraturan Menteri Kesehatan No.43 Tahun 2016 tentang Standar Pelayanan Minimal Bidang Kesehatan', 31 Agustus 2016.

(2014). Peraturan Menteri Kesehatan Republik Indonesia No.75 Tahun 2014: 12-13. Available at: binfar.kemkes.go.id/.

Korner M, Lippenberger C, Becker S Reich- 
ler L, Muller C, Zimmermenn L (2016). Knowledge Performance Integration, Teamwork and Performance in Health Care. Journal of Health Organization Management, 30(2).

Kustiyati S, et al. (2017). Determinan Faktor Yang Berhubungan Dengan Kinerja Bidan Dalam Program Perencanaan Persalinan Dan Pencegahan Komplikasi (P4K). Gaster, XV(1). Available at: http://jurnal.stikes-aisyiyah.ac.id/index.php/gaster/article/ viewFile/131/123.

Lucy KKL (2016). Effect of Leadership on Organizational Performance in the Health Sector in Kenya', International Journal of Scientific and Research Publications, 6(7): 658-663. Available at: www.ijsrp.org/research-paper0716.php?rp=P555655.

Marfu S, Tamtomo D, Suryono A (2016). Effect of Psychological Factors and Workload on Midwife Performance in the Integrated Antenatal Care in Pati , Central Java', 1: 138-145.

Mizawati A, Hakimi M, Kusnanto H (2016). Kinerja Bidan Desa Dalam Deteksi Dini Kasus Malaria: 31-40.

Sheard M (2009). Hardiness commitment, gender, and age differentiate university academic performance', British Journal of Educational Psychology, 79(1): 189-204. doi: 10.1348/000709908 X04406.

Wulanari A, Wigati PA, Sriatmi A (2017). Analisis Pelayanan Antenatal dan Faktor - Faktor yang Berkaitan dengan Cakupan Pelayanan Antenatal oleh Bidan. Jurnal Kesehatan Masyarakat, 5(1): 14-23.

Yeoh L, Hornetz K, Dahlui M (2016). Antenatal care utilisation and content between low-risk and high-risk pregnant women. PLoS ONE, 11(3): 1-17. doi: 10.1371/journal.pone.0152167. 